\title{
The Analysis and Countermeasures on College English Teaching Mode of Present Situation- Taking Yu Lin College as an Example
}

\author{
Xinzhuo Jiang ${ }^{1, a}$ and Jiang Liü, ${ }^{2}$ * \\ ${ }^{1}$ School of Foreign Languages, Yulin University, China, 719000 \\ ${ }^{2}$ School of Management, Yulin University, China, 719000 \\ a250883726@qq.com, ${ }^{\mathrm{b}}$ 52186531@qq.com
}

*The corresponding author

Keywords: Present situation; Reform; Countermeasures; Classroom effectiveness; New situation

\begin{abstract}
As the increasing growth of the reform and opening-up policy and the continuous development of the external association are picking up speed, not only those who are major in English but also the students of the non-English major are needed in this society to acquire basic English skills that are applied to social practice. College English education is an organic component of higher education. Therefore, it is an imminent problem which needs solving immediately to improve the level of college English teaching and the comprehensive quality of students' language learning. This article mainly talks about the current situation of college English teaching and English reform measures. The writer makes a summarization and put forward reform measures by giving out questionnaires and making a survey of many colleges.
\end{abstract}

\section{Introduction}

At present, both higher colleges and universities attach great importance to the improvement of college English levels. English has been getting more and more important to college students since the implementation of the CET4 and CET6 directed by the State Education Commission. However, with the deepening of the reform and opening-up policy and the rapid development of economic construction, the college English teaching is not optimistic. There are still some drawbacks. For example, the mode of college English teaching is single and obsolete, which makes students lose interests in learning English and lack the motivation of it. Meanwhile, it also leads to the phenomenon of "dead English". Over the years, the grammar-translation teaching method which views teachers as center occupies the absolute protagonist of the English teaching in our country. And even today, this kind of phenomenon also has no big differences. Therefore, college English teaching has always been a monodrama of the teachers, in which students are like the audiences or the listeners who seldom make practical communication and reply. This kind of unidirectional teaching mode objectively deprives students' opportunities to using languages and the habits of creative thinking. In the long term, it will make students lazier and make them become more dependent, so students' active study will become impossible. Two hours' classroom learning can hardly meet the requirements of the teaching. Neither can students get high effectiveness.

It has become a problem to be solved in today's college English teaching as to how to break the deep-rooted and traditional college English teaching theory and make the college English education keep pace with the increasing development of the information and economic society, the needs of the new era, and do its own optimizations. We must update the education concept, optimize the current teaching mode and explore a new mode of college English teaching, so as to improve the college teaching, and make the college English teaching adapt the requirements of social development to the cultivation of quality talents as far as possible. So, in combing with the teaching in recent years, through filed investigations, questionnaire, data analysis, and the current situation of English teaching and students' learning in other colleges, I find there are some questions existing in college English teaching including both teaching and learning in Yu Lin college like other colleges, and put forward corresponding countermeasures. 


\section{Some Questions Existing in College English Teaching}

The Exam-oriented Thought is Deep-rooted. The constraints of the traditional teaching concept on students' thoughts have not fully removed. A number of examinations including CET4, SET6, postgraduate examination, civil service examination, and requirements for all kinds of certificates cause students to study in a single teaching way which is exam-oriented. For students, learning is a process of rote, which can hardly make students truly understand the content and application of knowledge and realize the importance and practicability of learning, thus the true meaning and value of learning will be ignored and the motivation of learning actively and making progress will disappear. Combined with the students' learning situation in our college and the researches in other colleges and universities, I find this kind of attitude towards learning is a common problem.

Focus on the Theoretical Knowledge instead of Practical Contents. As a practical subject, English has a high requirement on listening, speaking, reading, writing and translating. However, today's teachings, which focus on the last two aspects, have not achieved a comprehensive and balanced state. This prevents those who are major in English to from communicating English fluently. They just use English in the classroom learning and there is little exercise after class. So a majority of students can pass the exams in writing but do badly in oral English or speaking tests.

The Teaching Mode is Single and the Innovation Consciousness Is Lacking. There used to be infusion education, in which students lack the consciousness of independent thinking and the ability of active learning. Therefore, the learning effects are usually low. Although innovations on new curriculum reforms have been taken, they fail to receive many effects to inspire the potential of students and establish their innovation consciousness. This kind of teaching mode is a common problem existing in English teaching in most of colleges.

There is Little Communication among the Same Majors of Colleges. Every college has its own teaching method and seldom communicates with other colleges in English teaching methods, which leads to a phenomenon where students are lack of platforms to communicate and opportunities to learn from each other. Thus, good learning method and teaching theory can hardly be shared. This kind of teaching method cannot be improved at all, and neither can it get innovation. It will over time form a certain teaching system and inherent pattern in each college. This is also an important factor which makes college English reform fail to achieve effectively.

Students cannot Realize the Importance of English Teaching Ideologically. As the reform of college entrance examination system, English isn't as important as it was before in many people's views. many student don't do a deep research on learning and few people like to consider its practical significance. Some students even think that college English courses are just minor subjects and their duties are to pass the examinations. But in today's global environment, English is becoming more and more important and it is also important to improve the ability of autonomous learning.

\section{The Reasons for the Present Situation of College English Teaching}

Students are Lack of the Motivation to Learn English. First of all, many students are not interested in learning English. They are lack of autonomous learning. They cannot arrange their time to learn English properly and find out the best way to learn it. Most students study English with a purpose of passing the examinations and get a graduation diploma. Second, traditional and old-fashioned teaching methods are not suitable for students to learn English. According to the survey, most kinds of college English classroom teaching still focus on the process in which teachers talk most of the time and students just make notes. When teachers teach them grammar, students usually recite it. When it comes to lessons, teachers usually translate the passages for them, and students will do the exercise by themselves. They will get the answers. The whole chapter, then, is finished. All in all, this kind of traditional and old teaching method cannot fully mobilize the enthusiasm of students' learning. The effects of the whole class are very low. If students spent no 
time reviewing and memorizing the lessons, the overall effect is close to zero.

Teachers Are not Familiar with the Teaching Material and Teaching Method. Most teachers are always using infusion ways to teach students in a lesson. They repeat what the book says, which leaves the students in a passive position. Thus, students are not interested in English. In addition, some teachers, who don't prepare a lesson carefully, are lack of a sense of responsibility. Their thoughts of muddling along seriously affect the whole quality of teaching. On the other hand, students have high expectations on teachers, hoping that they can learn and acquire knowledge through the classroom teaching. In their minds, what they have learned in the classroom is the main part of the lesson. They want to find a "shortcut" in this way. It they cannot achieve their goals, they will attribute the failure to teachers. For example, they will think teachers don't have the ability to teach, enough teaching experience or skills. Then students will have resistance to the course. This is a problem existing in the beginning stage of college teaching, and it is also a main reason for low teaching effects and students' learning efficiency.

College English Teaching is Constrained by Middle School English Teaching Mode. Middle school English teaching lays particular stress on knowledge and the cultivation of comprehensive ability. Although there are great changes and progress on teaching method, content, and detail steps in middle school English teaching in recent years, the main teaching mode, which is repeating what the book says and infusing knowledge into students' brains, is not changed. It lead to students' failure to acquire the ability of practical application and active learning. As a result, students' vocabulary becomes less. Though they are good at grammar, they cannot speak out fluently. They have problems in listening and writing. After they enter the college, they have to learn the basic knowledge and do some training from the beginning, which bring much burden to college English teaching. So the unreasonable middle school English teaching mode has an influence on college English teacher in some way.

\section{Countermeasures on College English Teaching Mode}

A key solution of the problems in college English teaching is to find out the right way, to adapt to new situation, and to reflect the requirements of new era. Not only should the students have a correct attitude towards learning, but the teachers also have to improve their innovative consciousness and quality. What's more, both the colleges and society should give their support to the education reform. Here, by researching the English teaching between our college and other colleges, I come up with several viewpoints on the problems in college English teaching.

Change the Teaching Theory and the Teaching Method. The main purpose of teaching is to make ourselves knowledgeable instead of passing the examinations or getting the certifications. Therefore, it is essential to learn with a purpose of learning. It needs the teachers and students communicate with each other closely. Only when the teachers change their ideas about learning and change the single and traditional teaching method for the heuristic teaching can they make the students change their old ideas about learning, so as to achieve the goal of learning actively.

Coordinate the Relationship between Theory and Practice and Make them Unite with each other. The purpose of learning English is not only to pass the examinations, but it also means improving ourselves. The essence of learning is to combine the theory with practice and make use of it in the daily life. This means we should have a better understanding on learning English and the abilities of using English and translation. Therefore, the coordinating development of listening, speaking, reading, writing and translating is an important ability that needs to be developed. This requires students to grasp every opportunity to practice and improve their abilities in the practice. Meanwhile, the college and teachers should provide the students with useful and valuable practical projects, making students learn English in the daily life, and live a better life though learning.

Open Multiple Model and Cultivate Innovative Consciousness. As for the inherent teaching mode, teachers should change the conventional teaching methods and explore students' potential from many aspects and angles. What's more, the students should not be obedient blindly all the time. Instead, they should come up with their own ideas. They should be brave enough to criticize, challenge and share their insights with teachers. Students are also supposed to change their inherent 
thinking patterns, plan and participate in all kinds of activities in professional training skills.

There is no Denying that the Old Teaching Mode cannot be Keep up with the Changing Social Situation. The collision of all kinds of new academic ideas in colleges and universities is bound to be a wonderful cultural feast. So it is time to set up a bridge of communication, which needs to expand the channel of communication in colleges and universities to provide teachers with more opportunities. It can also give students more learning resources, making them grasp more advances learning method and experience. At last, students can seek common ground while putting aside differences so as to get mutual promotion.

Strengthen the Ideological Education and Set up Correct Consciousness. The reform of college entrance examination system proves the importance of English in learning and communicating. The age is in progress and the thought is in the update. All kinds of thoughts collisions brought about by reform cannot weaken the influence of English. Correct consciousness should rely on the teachers' correct guidance. Students should attach importance to English from their heart and have a deep interest in English. Moreover, students should set up a new learning aim according to their own situations in learning English, and change the passive learning into active learning.

To sum up, the importance of English is evident and its teaching reform is imminent. In the global economic situation, both teachers and students should have a correct thought, which will play a part in improving the teaching effects. Only when we have a new idea, come up with a new thought and do a good job in teaching reform can we put English teaching to a new step, have a real teaching reform and make teaching have certain practical effects and significance. Thus, the overall level of education between teachers and students will be improved to a higher level.

\section{Acknowledgements}

Yulin College Teaching Reform Project in 2015(JG1521)

\section{References}

[1] Z.H. Li: Change Mode of Classroom Teaching: Constructivism Learning Theory and its Application in Teaching (Guangdong Education Press, China 2010) (In Chinese)

[2] Q.M. Ren: English Listening Teaching (Foreign Language Teaching and Research Press, China 2010) (In Chinese)

[3] D.F. Shu: Foreign Language Teaching and Research, Vol. 43 (2011) No.1, p.137 (In Chinese)

[4] L.Q. Zhu: Journal of Beijing University of Aeronautics and Astronautics(Social Sciences Edition), Vol.19 (2006) No.2, p.66 (In Chinese)

[5] L.J. Yao: Heilongjiang Researches on Higher Education, Vol. 240 (2014) No.4, p.167 (In Chinese)

[6] H.C. Zhang: Theory and Practice of Education, Vol.34 (2014) No.3, p.56 (In Chinese)

[7] Y.Q. Wang, W. Wang and L.B. Zhang: Foreign Language Education, Vol. 37(2016) No5, p.42 (In Chinese)

[8] L.T and L.B. Wang: Foreign Language, Vol. 37(2016) No5, p.42 (In Chinese)

[9] J.W. ZHang: Foreign Language Education, Vol. 37(2016) No3, p.66 (In Chinese)

[10] X.X. Wu: Foreign Language Education, Vol. 36 (2015) No.4, p.60 (In Chinese) 